\title{
Progranulin haploinsufficiency reduces amyloid beta deposition in Alzheimer's disease model mice
}

\author{
Masato HOSOKAWA ${ }^{1)}$, Yoshinori TANAKA ${ }^{1)}$, Tetsuaki ARAI ${ }^{1,2)}$, Hiromi KONDO ${ }^{3)}$, \\ Haruhiko AKIYAMA ${ }^{1)}$, and Masato HASEGAWA ${ }^{1)}$ \\ 1) Dementia research project, Department of Dementia and Higher Brain Function, Tokyo Metropolitan Institute of \\ Medical Science, 2-1-6 Kamikitazawa, Setagaya-ku, Tokyo 156-8506, Japan \\ ${ }^{2)}$ Department of Neuropsychiatry, Division of Clinical Medicine, Faculty of Medicine, University of Tsukuba, \\ 1-1-1, Tennodai, Tsukuba, Ibaraki 305-8576 Japan \\ ${ }^{3)}$ Histology center, Tokyo Metropolitan Institute of Medical Science, 2-1-6 Kamikitazawa, Setagaya-ku, Tokyo \\ 156-8506, Japan
}

\begin{abstract}
Granulin (Grn) mutations were identified in familial frontotemporal lobar degeneration (FTLD) patients with TAR DNA-binding protein of $43 \mathrm{kd}$ (TDP-43) pathology. Grn transcript haploinsufficiency is proposed as a disease mechanism that leads to the loss of functional progranulin (PGRN) protein. Thus, these mutations are strongly involved in FTLD pathogenesis. Moreover, recent findings indicate that $\mathrm{Grn}$ mutations are associated with other neurodegenerative disorders with tau pathology, including Alzheimer's disease. To investigate the influence of PGRN on amyloid beta (A $\beta)$ accumulation, amyloid precursor protein (APP) transgenic mice were interbred with Grn-deficient mice, producing APP transgenic mice harboring the $G r n$ hemizygote (APP/Grn ${ }^{+/-}$). Brains were collected from 16-18-month-old APP and APP/ $\mathrm{Grn}^{+/-}$mice and sequential extraction of proteins, immunoblotting and immunohistochemical analysis were performed. Immunohistochemical analysis showed that the number and area of A $\beta$ plaque was significantly decreased in APP $/ \mathrm{Grn}^{+/-}$mice as compared to APP mice. Immunoblotting analysis revealed that A $\beta$ was reduced in the sarkosylinsoluble fraction of 16-18-month-old APP/ $\mathrm{Grn}^{+-}$mice as compared with that of APP transgenic mice. Our data suggest that PGRN haploinsufficiency may decrease accumulation of $A \beta$.
\end{abstract}

Key words: Alzheimer's disease, amyloid beta $(A \beta)$, granulin, haploinsufficiency, progranulin

\section{Introduction}

Progranulin (PGRN) is a growth factor which is encoded by a single gene on chromosome $17 \mathrm{q} 21$. It is a 593-amino acid, cysteine-rich protein with a signal peptide (17 amino acids) and highly conserved 7.5 tandem granulin repeats of a 12 cysteinyl motif. PGRN is involved in the regulation of multiple functions, including neuronal cell growth $[7,36]$, wound healing $[11,38]$ and inflammation [37]. It has also been strongly linked to tumorigenesis [26]. Moreover, it has a chemoattractive effect for microglia [28]. In 2006, granulin $(G R N)$ null mutations were identified in familial frontotemporal dementia (FTD) linked to chromosome 17q21 with taunegative, ubiquitin-positive inclusions. Many mutations, including frame shift by insertion and deletion or substitution of a nucleotide, have been reported, which generate premature termination codons. GRN transcript

(Received 23 May 2017 / Accepted 7 August 2017 / Published online in J-STAGE 25 August 2017)

Address corresponding: M. Hosokawa, Dementia Research Project, Department of Dementia and Higher Brain Function, Tokyo Metropolitan Institute of Medical Science, 2-1-6 Kamikitazawa, Setagaya-ku, Tokyo 156-8506, Japan

c) $\$($ This is an open-access article distributed under the terms of the Creative Commons Attribution Non-Commercial No Derivatives (by-nc-nd) License <http://creativecommons.org/licenses/by-nc-nd/4.0/>.

(C)2018 Japanese Association for Laboratory Animal Science 
haploinsufficiency is the proposed disease mechanism that leads to the loss of functional PGRN protein. Premature stop codons are not translated into the mutant transcript, since translation is blocked by nonsensemediated RNA decay. The mutation in the signal peptide may cause mislocalization of PGRN in a protein secretion pathway or PGRN loss of function by impairment of PGRN transport $[1,25]$. Thus, these mutations are strongly involved in FTD pathogenesis.

GRN mutations causing loss of function have been confirmed in patients clinically diagnosed with Alzheimer's disease (AD) [3-6, 9, 16, 18-20, 30]. The rs5848 $\left(3^{\prime} \mathrm{UTR}+78 \mathrm{C}>\mathrm{T}\right)$ variant in the $3^{\prime}$ untranslated region of $G R N$ is known to reduce GRN mRNA levels in the brain and peripheral mononuclear cells in patients. The rs5848 variant was also found in $\mathrm{AD}[8]$ and associated with a risk for $\mathrm{AD}$ [21]. GRN mutations were also found in corticobasal syndrome, another tauopathy $[1,2,23$, $27,31]$. These findings suggest that decline or dysfunction of PGRN may cause tau abnormalities, leading to the formation of tau pathology by activation of cyclin dependent kinases (CDKs) [12], TYROBP network genes [32] or lysosomal dysfunction [33, 35].

There has been an interesting report by Minami et al. [24] on A $\beta$ accumulation with GRN deficiency. They used APPhigh LysM-cre ${ }^{+} G n^{\text {flox/flox }}$ mice and showed that PGRN reduction increased $A \beta$ deposition in these mice model and that overexpression of PGRN by lentivirus decreased $\mathrm{A} \beta$ plaque load. Very recently, Takahashi et al. [32] reported that APP/PS1 mice harbouring the Grn homozygote knock-out (APP/PS1/Grn ${ }^{-1-}$ mice) exhibited less $A \beta$ pathology. These two reports suggested that PGRN null condition might affect $A \beta$ pathology in mice. However, the influence of PGRN haploinsufficiency on $\mathrm{A} \beta$ accumulation is still unknown.

To investigate the influence of PGRN haploinsufficiency $\left(\mathrm{Grn}^{+-}\right)$on A $\beta$ accumulation, we produced APP transgenic mice harboring the Grn hemizygote (APP/ $\mathrm{Grn}^{+-}$) by interbreeding APP transgenic mice with Grndeficient mice, and found that the PGRN haploinsufficiency decreases $\mathrm{A} \beta$ deposition.

\section{Materials and Methods}

\section{Ethics Statement}

This study was carried out in strict accordance with the recommendations provided in the Guide for the Care and Use of Laboratory Animals of the Ministry of Health,
Labour and Welfare of Japan and the Ministry of Education, Culture, Sports, Science and Technology of Japan. The protocol was approved by the Committee on the Ethics of Animal Experiments of the Tokyo Metropolitan Institute of Medical Science (Permit Numbers: 22-23 and 11-028). All experiments were performed under isofluran anesthesia and every effort was made to minimize suffering.

\section{Animals}

The APP transgenic mice (Tg2576) [15] were purchased from Taconic (Hudson, NY, USA). Granulin (Grn) deficient (knock-out: KO) mice were obtained from RIKEN Bioresource Center (Tsukuba, Japan), which was established by Kayasuga et al. [17]. Grn-KO $\left(\mathrm{Grn}^{-/-}\right)$mice had been back-crossed to C57BL/6J mice for more than 10 generations. Male APP homozygote transgenic mice were interbred with female Grn-KO mice so that APP transgenic mice harboring the Grn hemizygote (APP/ $\mathrm{Grn}^{+/-}$) were produced. Control mice (APP hemizygote) were produced by interbreeding male APP homozygote transgenic mice and female C57BL/6J mice. We used three female APP mice and three female APP $/ \mathrm{Grn}^{+/-}$mice (age range: $16-18$-month-old) in this study. Minami et al. reported that PGRN expression level of $\mathrm{Grn}^{+/-}$mice was half of the wild type mice $\left(\mathrm{Grn}^{+/+}\right)$[24]. The mice were reared in the animal facility of Tokyo Metropolitan Institute of Medical Science under conventional conditions at $24 \pm 2{ }^{\circ} \mathrm{C}$ and were maintained on a commercial diet (CE-2, Nihon CLEA, Shizuoka, Japan) ad libitum.

Mice were sacrificed under quick anesthesia with isofluran (Mylan Pharmaceutical Co., Ltd., Tokyo, Japan) and the brains were removed quickly. Brains of each group were cut in the sagittal plane and the left hemisphere was frozen and stored at $-80^{\circ} \mathrm{C}$ for biochemical analyses. The right hemisphere was fixed in $4 \%$ paraformaldehyde in $0.1 \mathrm{M}$ phosphate buffer for $36 \mathrm{~h}$ at $4^{\circ} \mathrm{C}$. Brain blocks were then transferred to a maintenance solution of $20 \%$ sucrose in $0.01 \mathrm{M}$ PBS, pH 7.4.

\section{Sequential fractionation of brain extracts}

Frozen left hemispheres (approximately, $0.2 \mathrm{~g}$ ) were homogenized in 10 volumes of buffer $\mathrm{H}(10 \mathrm{mM}$ Tris$\mathrm{HCl}, \mathrm{pH} 7.5,0.8 \mathrm{M} \mathrm{NaCl}, 1 \mathrm{mM}$ ethylene glycol bis-N, $\mathrm{N}, \mathrm{N}$ ', N'-tetraacetic acid, $1 \mathrm{mM}$ dithiothreitol). The hemisphere included the olfactory bulb, cerebral cortex, striatum, thalamus, hypothalamus, cerebellum, midbrain, 
pons, medulla oblongata and the upper part of the spinal cord. The method used for sequential fractionation of brain extracts was originally described by Greenberg et al. [10]. Briefly, each brain homogenate was centrifuged at $100,000 \times \mathrm{g}$ for $20 \mathrm{~min}$ at $4^{\circ} \mathrm{C}$, and the supernatant was collected as the Tris-soluble fraction. The resultant pellet was homogenized in 10 volumes of buffer $\mathrm{H}$, followed by an incubation for $30 \mathrm{~min}$ at $37^{\circ} \mathrm{C}$ with $1 \%$ Triton X-100. The homogenate was then centrifuged at $100,000 \times \mathrm{g}$ for $20 \mathrm{~min}$ at $4^{\circ} \mathrm{C}$. The Triton X-100 insoluble pellet was sonicated in 5 volumes of buffer $\mathrm{H}$, followed by an incubation for $30 \mathrm{~min}$ at $37^{\circ} \mathrm{C}$ with $1 \%$ sarkosyl and centrifuged at $100,000 \times \mathrm{g}$ for $20 \mathrm{~min}$ at $4^{\circ} \mathrm{C}$. The pellet was sonicated in 1 volume of SDS-PAGE sample buffer [13].

\section{Immunoblotting analysis}

For immunoblotting, brain extracts from the mice were boiled for $5 \mathrm{~min}$ with SDS-PAGE sample buffer $(60 \mathrm{mM}$ Tris-HCl, pH 6.8, containing 2\% SDS, $10 \%$ glycerol, $0.025 \%$ bromophenol blue and $5 \%$ mercaptoethanol) and loaded onto a $10 \%$ acrylamide minigel. Loaded samples were electrophoresed for $45 \mathrm{~min}$ at $200 \mathrm{~V}$ with molecular weight markers (Bio-Rad, Hercules, CA, USA). Electrophoresed proteins were transferred onto a polyvinylidene difluoride membrane (Millipore, Billerica, MA, USA) for $60 \mathrm{~min}$ at $200 \mathrm{~mA}$. The printed membranes were blocked with $3 \%$ gelatin for $30 \mathrm{~min}$ and then incubated in a primary antibody solution (6E10, 1:1,000, Covance, Dedham MA, USA or anti- $\alpha$-tubulin, 1:10,000, Sigma, St. Louis, MO, USA) overnight at room temperature. Antibody labeling was performed by incubation with horse radish peroxidase-conjugated anti-mouse $\operatorname{IgG}$ (1:50,000, Bio-Rad) for $1 \mathrm{~h}$. Following incubation with avidin-biotinylated horseradish peroxidase complex (ABC Elite, Vector Laboratories, 1:400), immunoreactivity was detected by the chemiluminescence method using a Super Signal West Dura (Thermo Scientific, West Palm Beach, FL, USA) and was visualized with LAS-4000 mini (GE Healthcare UK Ltd.). Densitometric analysis of $A \beta$ level was performed using Image $J$ software (National Institutes of Health, Bethesda, MD, USA).

\section{Analysis of $A \beta$ deposition}

For $\mathrm{A} \beta$ immunohistochemistry, sagittal sections from left hemisphere were cut serially on a freezing microtome at $30 \mu \mathrm{m}$ thickness, collected in the maintenance solution, and immunostained as free-floating sections. Sections were incubated for $24 \mathrm{~h}$ with biotinylated anti-A $\beta$ antibody (6E10). The antibody labeling was visualized by incubation with avidin-biotinylated horseradish peroxidase complex (ABC Elite, Vector Laboratories, 1:1,000) for $3 \mathrm{~h}$, followed by incubation with a solution containing $0.01 \%$ 3,3'-diaminobenzidine (DAB), $1 \%$ nickel ammonium sulfate, $0.05 \mathrm{M}$ imidazole and $0.00015 \% \mathrm{H}_{2} \mathrm{O}_{2}$ in $0.05 \mathrm{M}$ Tris-HCl buffer, $\mathrm{pH}$ 7.6. Counter nuclear staining was performed with Kernechtrot stain solution (Merck, Darmstadt, Germany). The sections were then rinsed with distilled water, mounted on glass slides, treated with xylene, and coverslipped with Entellan (Merck).

Photographs were taken with a BZ-X710 (Keyence, Osaka, Japan). The dark-purple plaques were counted in the area of the cerebral cortex and hippocampus. Two sagittal sections from each mouse were subjected to counts of the $A \beta$ plaque number and area by Keyence BZ-710.

\section{Statistical Analysis of A $\beta$ deposition}

Data are presented as mean \pm SE. The statistical significance of differences in the mean values between 2 populations was assessed with the Student $t$-test, whether variances were equal was determined by an F-test, and otherwise we used Mann-Whitney's $U$-test. $P<0.05$ was considered significant.

\section{Results}

A $\beta$ deposition was decreased in APP/Grn ${ }^{+/-}$mice by immunohistochemical staining

Brains were collected from 16-18-month-old mice of APP or APP $/ \mathrm{Grn}^{+/-}$and immunohistochemical staining was performed. $\mathrm{A} \beta$ deposition was visualized using an anti-A $\beta$ antibody, 6E10. A 6E10 immunoreaction was observed in the cortex and hippocamups of APP mouse and APP $/ \mathrm{Grn}^{+/-}$mouse (Fig. 1A). Two sagittal sections from each mouse were subjected to counts of the $A \beta$ plaque number and area by Keyence BZ-710. The number of $6 \mathrm{E} 10$ positive $\mathrm{A} \beta$ plaques which were larger than $4 \mu \mathrm{m}^{2}$ in the cortex and hippocampus was significantly decreased in APP/ $\mathrm{Grn}^{+/-}$mice (441 \pm 5$)$ compared with APP mice ( $978 \pm 149)(P=0.0495$ by Mann-Whitney's $U$-test) (Fig. 1B). The area of 6E10 positive plaques was also significantly decreased in APP/ $\mathrm{Grn}^{+/-}$mice $(181,358$ $\left.\pm 15,246 \mu \mathrm{m}^{2}\right)$ compared with APP mice $(412,777 \pm$ $\left.53,369 \mu \mathrm{m}^{2}\right)(P=0.014$ by Student $t$-test $)$ (Fig. 1C). 


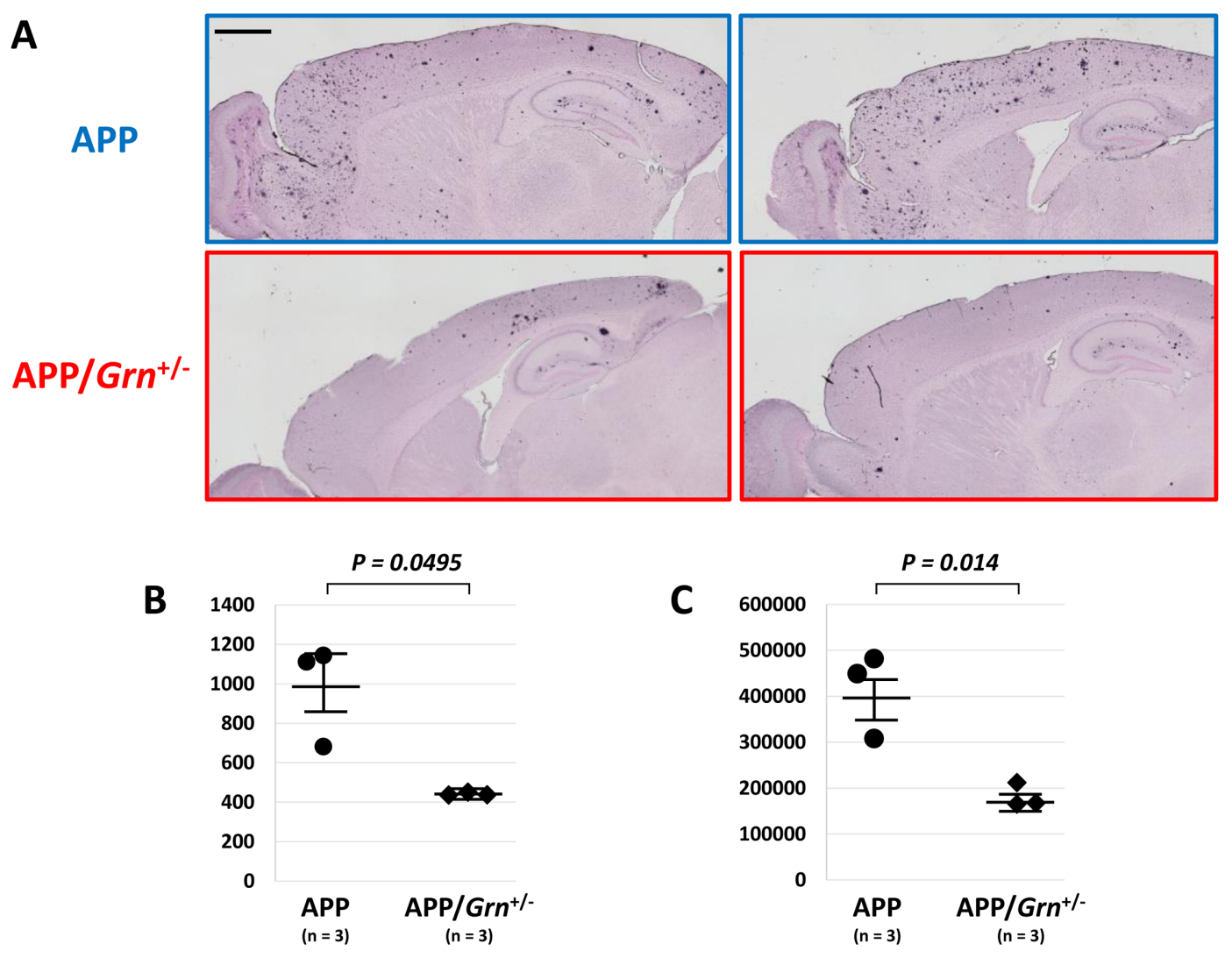

Fig. 1. Immunohistochemical analysis of $A \beta$ deposition in 16-18-month-old APP or APP/ $\mathrm{Grn}^{+/-}$mice. (A) Immunohistochemical analysis was visualized using the $6 \mathrm{E} 10$ antibody for detecting $\mathrm{A} \beta$ deposition in 16-18-monthold APP or APP $/ \mathrm{Grn}^{+/-}$mice. The scale bar applies to all photomicrographs (1.0 mm). (B, C) A comparison of relative $A \beta$ plaque number $(B)$ and area $(C)$ in 16-18-month-old mice. The $A \beta$ plaque numbers and areas of $\mathrm{A} \beta$ deposition $\left(\mu \mathrm{m}^{2}\right)$ in the two different strains were compared. Two sagittal sections from each mouse were subjected to counts of the $A \beta$ plaque number and area, then the average of them were plotted on the graph. $P<0.05$ was considered to represent a statistically significant difference.

A $\beta$ deposition was decreased in the sarkosyl-insoluble fraction of $\mathrm{APP} / \mathrm{Grn}^{+/-}$mice

Brains were collected from 16-18-month-old mice of $\mathrm{APP}$ or APP $/ \mathrm{Grn}^{+/-}$, then sequential protein extraction and immunoblotting were performed. $A \beta$ in the sarkosylinsoluble fraction was visualized by Western blotting using the $6 \mathrm{E} 10$ antibody. The results suggest that the level of sarkosyl-insoluble $\mathrm{A} \beta$ was decreased in the APP/ $\mathrm{Grn}^{+/-}$mice $(\mathrm{n}=3)$ as compared with the APP mice $(\mathrm{n}=3)$ (Fig. 2A). The $A \beta$ level in sarkosyl-insoluble fraction was significantly decreased in APP/ $\mathrm{Grn}^{+/-}$mice $(19,719.8$ \pm 936.7) compared with APP mice $(35,148.3 \pm 3,007.0)$ by the densitometric analysis. $(P=0.009$ by Student $t$ test) (Fig. 2B). The A $\beta 40$ and A $\beta 42$ levels in Tris-soluble fraction were no significant differences between APP and APP/ $\mathrm{Grn}^{+/-}$mice by ELISA (data not shown).

Discussion

The results of the present study show that PGRN haploinsufficiency reduce $A \beta$ deposition in the APP mice. It suggests that $G R N$ mutations causing PGRN reduction may not be causative or risk factor for $\mathrm{A} \beta$ pathology. However, our previous report suggested that PGRN haploinsufficiency may cause tau abnormalities, leading to the formation of tau pathology by activation of CDKs [12]. Very recently, we have revealed that accumulation of phosphorylated tau was found in the brains of FTLD associated with $G R N$ mutation [14].

These opposing effects of GRN deficiency against $\mathrm{A} \beta$ and tau might be explained as follows. Microglia produce PGRN and it suppresses hyper-activation of microglia by an autocrine effect [34]. PGRN deficiency may cause activation of microglia and they phagocyte extracellular 
A

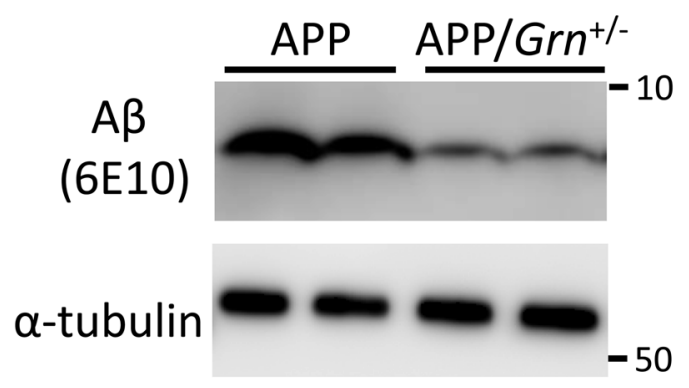

B

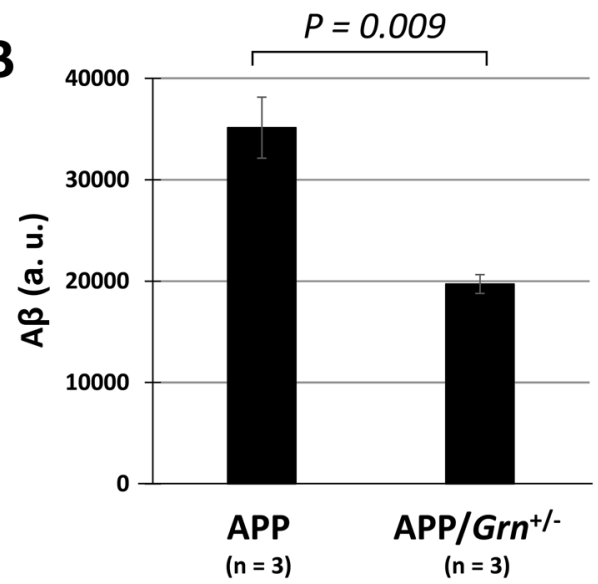

Fig. 2. Immunoblotting analysis of $A \beta$ deposition for the sarkosyl-insoluble fraction in 16-18-month-old APP or $\mathrm{APP} / \mathrm{Grn}^{+/-}$mice. (A) Immunoblotting analysis was visualized using the $6 \mathrm{E} 10$ antibody for detecting A $\beta$ deposition in the sarkosyl-insoluble fraction of 16-18-month-old APP or APP/ $\mathrm{Grn}^{+/-}$mice. Molecular weight markers are shown on the right $(\mathrm{kDa})$. (B) Densitometric analysis of $\mathrm{A} \beta$ level in sarkosyl-insoluble fraction. $P<0.05$ was considered to represent a statistically significant difference. a.u., arbitrary unit.

A $\beta$. On the other hand, PGRN deficiency leads to lysosomal dysfunction in neuronal cells and may thus favor abnormal tau deposition. A schematic diagram of the opposing effects of GRN deficiency against $\mathrm{A} \beta$ and tau is shown in Fig. 3.

The inference of PGRN reduction on $\mathrm{A} \beta$ accumulation, has been reported by Minami et al. [24]. They used APPhigh ${ }^{2 y s M-c r e}{ }^{+} G r n^{\text {flox/flox }}$ mice and showed that PGRN reduction increased $A \beta$ plaque load in these mice model. The discrepancy between their results and ours might be explained by the difference in mouse strain as indicated in a recent study [32]. APPhigh LysM-cre ${ }^{+}$Grnflox/flox conditional mice were used in their study and LysM-cre mice lack endogenous $L y z 2$, which is markedly increased in $\mathrm{Grn}^{-/-}$mice $[22,29]$. Microglia from $\mathrm{Grn}^{-/-}$mice showed upregulation of phagocytic activity [32], but phagocytic activitiy was down-regulated in APP ${ }^{\text {high }}$ LysM-cre ${ }^{+} n^{\text {flox/flox }}$ mice [24].

Recently, Takahashi et al. [32] reported that global PGRN reduction induces microglial TYROBP network genes expression and increases AD risk by exacerbating neuronal injury and tau pathology, rather than by accelerating $A \beta$ pathology [32]. They utilized APP/PS1$\mathrm{Grn}^{+/+},-\mathrm{Grn}^{+/-}$, and $-\mathrm{Grn}^{-/-}$mice. The APP/PS1- $\mathrm{Grn}^{-/-}$ mice showed reduction of $\mathrm{A} \beta$ deposition compared with 16-month old APP/PS1-Grn ${ }^{+/+}$or APP/PS1-Grn ${ }^{+/-}$mice. Their study could not elucidate the effect of PGRN haploinsufficiency on $A \beta$ deposition. However, global PGRN reduction decreased $A \beta$ accumulation clearly. Their re-

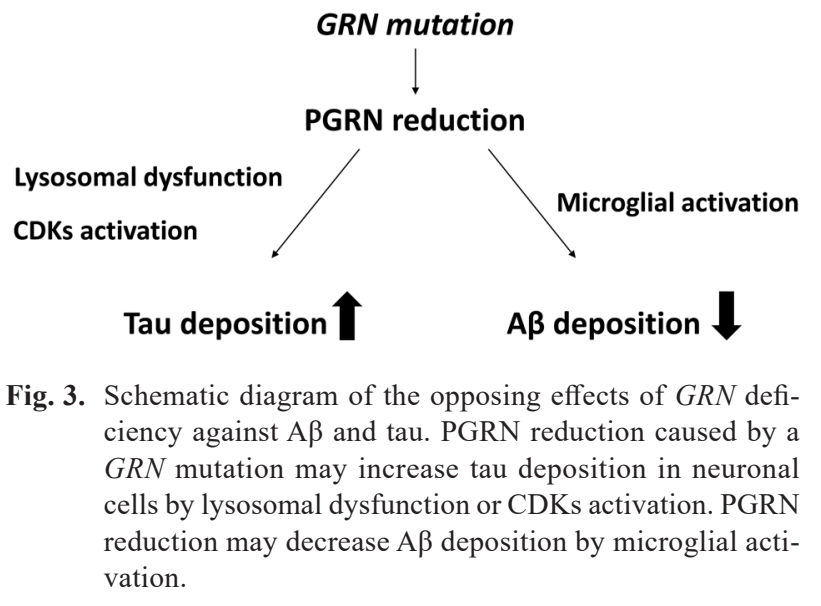

sults supported our previous report [12] and this study.

Our results suggested that PGRN haploinsufficiency may reduce $A \beta$ deposition and may not be causative or represent a risk factor for $A \beta$ pathology.

\section{Conflict of Interest}

None declared.

\section{Acknowledgments}

This research was partially supported by the Japan Society for the Promotion of Science, Grant-in-Aid for Scientific Research (C) [JSPS KAKENHI grant number 24591738] to MHosokawa. Additional funding for our 
study was supplied by our institute. The authors would like to thank Dr. Edith G. McGeer for editing of the manuscript.

\section{References}

1. Baker, M., Mackenzie, I.R., Pickering-Brown, S.M., Gass, J., Rademakers, R., Lindholm, C., Snowden, J., Adamson, J., Sadovnick, A.D., Rollinson, S., Cannon, A., Dwosh, E., Neary, D., Melquist, S., Richardson, A., Dickson, D., Berger, Z., Eriksen, J., Robinson, T., Zehr, C., Dickey, C.A., Crook, R., McGowan, E., Mann, D., Boeve, B., Feldman, H., and Hutton, M. 2006. Mutations in progranulin cause tau-negative frontotemporal dementia linked to chromosome 17. Nature 442: 916-919. [Medline] [CrossRef]

2. Benussi, L., Binetti, G., Sina, E., Gigola, L., Bettecken, T., Meitinger, T., and Ghidoni, R. 2008. A novel deletion in progranulin gene is associated with FTDP-17 and CBS. Neurobiol. Aging 29: 427-435. [Medline] [CrossRef]

3. Brouwers, N., Nuytemans, K., van der Zee, J., Gijselinck, I., Engelborghs, S., Theuns, J., Kumar-Singh, S., Pickut, B.A., Pals, P., Dermaut, B., Bogaerts, V., De Pooter, T., Serneels, S., Van den Broeck, M., Cuijt, I., Mattheijssens, M., Peeters, K., Sciot, R., Martin, J.J., Cras, P., Santens, P., Vandenberghe, R., De Deyn, P.P., Cruts, M., Van Broeckhoven, C., and Sleegers, K. 2007. Alzheimer and Parkinson diagnoses in progranulin null mutation carriers in an extended founder family. Arch. Neurol. 64: 1436-1446. [Medline] [CrossRef]

4. Brouwers, N., Sleegers, K., Engelborghs, S., Maurer-Stroh, S., Gijselinck, I., van der Zee, J., Pickut, B.A., Van den Broeck, M., Mattheijssens, M., Peeters, K., Schymkowitz, J., Rousseau, F., Martin, J.J., Cruts, M., De Deyn, P.P., and Van Broeckhoven, C. 2008. Genetic variability in progranulin contributes to risk for clinically diagnosed Alzheimer disease. Neurology 71: 656-664. [Medline] [CrossRef]

5. Carecchio, M., Fenoglio, C., De Riz, M., Guidi, I., Comi, C., Cortini, F., Venturelli, E., Restelli, I., Cantoni, C., Bresolin, N., Monaco, F., Scarpini, E., and Galimberti, D. 2009. Progranulin plasma levels as potential biomarker for the identification of GRN deletion carriers. A case with atypical onset as clinical amnestic Mild Cognitive Impairment converted to Alzheimer's disease. J. Neurol. Sci. 287: 291-293. [Medline] [CrossRef]

6. Cortini, F., Fenoglio, C., Guidi, I., Venturelli, E., Pomati, S., Marcone, A., Scalabrini, D., Villa, C., Clerici, F., Dalla Valle, E., Mariani, C., Cappa, S., Bresolin, N., Scarpini, E., and Galimberti, D. 2008. Novel exon 1 progranulin gene variant in Alzheimer's disease. Eur. J. Neurol. 15: 1111-1117. [Medline] [CrossRef]

7. Daniel, R., Daniels, E., He, Z., and Bateman, A. 2003. Progranulin (acrogranin/PC cell-derived growth factor/granulinepithelin precursor) is expressed in the placenta, epidermis, microvasculature, and brain during murine development. Dev. Dyn. 227: 593-599. [Medline] [CrossRef]

8. Fenoglio, C., Galimberti, D., Cortini, F., Kauwe, J.S., Cruchaga, C., Venturelli, E., Villa, C., Serpente, M., Scalabrini, D., Mayo, K., Piccio, L.M., Clerici, F., Albani, D., Mariani,
C., Forloni, G., Bresolin, N., Goate, A.M., and Scarpini, E. 2009. Rs5848 variant influences GRN mRNA levels in brain and peripheral mononuclear cells in patients with Alzheimer's disease. J. Alzheimers Dis. 18: 603-612. [Medline] [CrossRef]

9. Finch, N., Baker, M., Crook, R., Swanson, K., Kuntz, K., Surtees, R., Bisceglio, G., Rovelet-Lecrux, A., Boeve, B., Petersen, R.C., Dickson, D.W., Younkin, S.G., Deramecourt, V., Crook, J., Graff-Radford, N.R., and Rademakers, R. 2009. Plasma progranulin levels predict progranulin mutation status in frontotemporal dementia patients and asymptomatic family members. Brain 132: 583-591. [Medline] [CrossRef]

10. Greenberg, S.G. and Davies, P. 1990. A preparation of Alzheimer paired helical filaments that displays distinct tau proteins by polyacrylamide gel electrophoresis. Proc. Natl. Acad. Sci. USA 87: 5827-5831. [Medline] [CrossRef]

11. He, Z., Ong, C.H., Halper, J., and Bateman, A. 2003. Progranulin is a mediator of the wound response. Nat. Med. 9: 225-229. [Medline] [CrossRef]

12. Hosokawa, M., Arai, T., Masuda-Suzukake, M., Kondo, H., Matsuwaki, T., Nishihara, M., Hasegawa, M., and Akiyama, H. 2015. Progranulin reduction is associated with increased tau phosphorylation in P301L tau transgenic mice. J. Neuropathol. Exp. Neurol. 74: 158-165. [Medline] [CrossRef]

13. Hosokawa, M., Arai, T., Masuda-Suzukake, M., Nonaka, T., Yamashita, M., Akiyama, H., and Hasegawa, M. 2012. Methylene blue reduced abnormal tau accumulation in P301L tau transgenic mice. PLoS One 7: e52389. [Medline] [CrossRef]

14. Hosokawa, M., Kondo, H., Serrano, G.E., Beach, T.G., Robinson, A.C., Mann, D.M., Akiyama, H., Hasegawa, M., and Arai, T. 2017. Accumulation of multiple neurodegenerative disease-related proteins in familial frontotemporal lobar degeneration associated with granulin mutation. Sci. Rep. 7: 1513. [Medline] [CrossRef]

15. Hsiao, K., Chapman, P., Nilsen, S., Eckman, C., Harigaya, Y., Younkin, S., Yang, F., and Cole, G. 1996. Correlative memory deficits, Abeta elevation, and amyloid plaques in transgenic mice. Science 274: 99-102. [Medline] [CrossRef]

16. Josephs, K.A., Ahmed, Z., Katsuse, O., Parisi, J.F., Boeve, B.F., Knopman, D.S., Petersen, R.C., Davies, P., Duara, R., Graff-Radford, N.R., Uitti, R.J., Rademakers, R., Adamson, J., Baker, M., Hutton, M.L., and Dickson, D.W. 2007. Neuropathologic features of frontotemporal lobar degeneration with ubiquitin-positive inclusions with progranulin gene (PGRN) mutations. J. Neuropathol. Exp. Neurol. 66: 142151. [Medline] [CrossRef]

17. Kayasuga, Y., Chiba, S., Suzuki, M., Kikusui, T., Matsuwaki, T., Yamanouchi, K., Kotaki, H., Horai, R., Iwakura, Y., and Nishihara, M. 2007. Alteration of behavioural phenotype in mice by targeted disruption of the progranulin gene. Behav. Brain Res. 185: 110-118. [Medline] [CrossRef]

18. Kelley, B.J., Haidar, W., Boeve, B.F., Baker, M., Graff-Radford, N.R., Krefft, T., Frank, A.R., Jack, C.R. Jr., Shiung, M., Knopman, D.S., Josephs, K.A., Parashos, S.A., Rademakers, R., Hutton, M., Pickering-Brown, S., Adamson, J., Kuntz, 
K.M., Dickson, D.W., Parisi, J.E., Smith, G.E., Ivnik, R.J., and Petersen, R.C. 2009. Prominent phenotypic variability associated with mutations in Progranulin. Neurobiol. Aging 30: 739-751. [Medline] [CrossRef]

19. Kelley, B.J., Haidar, W., Boeve, B.F., Baker, M., Shiung, M., Knopman, D.S., Rademakers, R., Hutton, M., Adamson, J., Kuntz, K.M., Dickson, D.W., Parisi, J.E., Smith, G.E., and Petersen, R.C. 2010. Alzheimer disease-like phenotype associated with the c.154delA mutation in progranulin. Arch. Neurol. 67: 171-177. [Medline] [CrossRef]

20. Le Ber, I., Camuzat, A., Hannequin, D., Pasquier, F., Guedj, E., Rovelet-Lecrux, A., Hahn-Barma, V., van der Zee, J., Clot, F., Bakchine, S., Puel, M., Ghanim, M., Lacomblez, L., Mikol, J., Deramecourt, V., Lejeune, P., de la Sayette, V., Belliard, S., Vercelletto, M., Meyrignac, C., Van Broeckhoven, C., Lambert, J.C., Verpillat, P., Campion, D., Habert, M.O., Dubois, B., Brice, A., French research network on FTD/FTD-MND 2008. Phenotype variability in progranulin mutation carriers: a clinical, neuropsychological, imaging and genetic study. Brain 131: 732-746. [Medline] [CrossRef]

21. Lee, M.J., Chen, T.F., Cheng, T.W., and Chiu, M.J. 2011. rs5848 variant of progranulin gene is a risk of Alzheimer's disease in the Taiwanese population. Neurodegener. Dis. 8: 216-220. [Medline] [CrossRef]

22. Lui, H., Zhang, J., Makinson, S.R., Cahill, M.K., Kelley, K.W., Huang, H.Y., Shang, Y., Oldham, M.C., Martens, L.H., Gao, F., Coppola, G., Sloan, S.A., Hsieh, C.L., Kim, C.C., Bigio, E.H., Weintraub, S., Mesulam, M.M., Rademakers, R., Mackenzie, I.R., Seeley, W.W., Karydas, A., Miller, B.L., Borroni, B., Ghidoni, R., Farese, R.V. Jr., Paz, J.T., Barres, B.A., and Huang, E.J. 2016. Progranulin Deficiency Promotes Circuit-Specific Synaptic Pruning by Microglia via Complement Activation. Cell 165: 921-935. [Medline] [CrossRef]

23. Masellis, M., Momeni, P., Meschino, W., Heffner, R. Jr., Elder, J., Sato, C., Liang, Y., St George-Hyslop, P., Hardy, J., Bilbao, J., Black, S., and Rogaeva, E. 2006. Novel splicing mutation in the progranulin gene causing familial corticobasal syndrome. Brain 129: 3115-3123. [Medline] [CrossRef]

24. Minami, S.S., Min, S.W., Krabbe, G., Wang, C., Zhou, Y., Asgarov, R., Li, Y., Martens, L.H., Elia, L.P., Ward, M.E., Mucke, L., Farese, R.V. Jr., and Gan, L. 2014. Progranulin protects against amyloid $\beta$ deposition and toxicity in Alzheimer's disease mouse models. Nat. Med. 20: 1157-1164. [Medline] [CrossRef]

25. Mukherjee, O., Pastor, P., Cairns, N.J., Chakraverty, S., Kauwe, J.S., Shears, S., Behrens, M.I., Budde, J., Hinrichs, A.L., Norton, J., Levitch, D., Taylor-Reinwald, L., Gitcho, M., Tu, P.H., Tenenholz Grinberg, L., Liscic, R.M., Armendariz, J., Morris, J.C., and Goate, A.M. 2006. HDDD2 is a familial frontotemporal lobar degeneration with ubiquitinpositive, tau-negative inclusions caused by a missense mutation in the signal peptide of progranulin. Ann. Neurol. 60: 314-322. [Medline] [CrossRef]

26. Ong, C.H. and Bateman, A. 2003. Progranulin (granulin-epithelin precursor, PC-cell derived growth factor, acrogranin) in proliferation and tumorigenesis. Histol. Histopathol. 18: 1275-1288. [Medline]

27. Perry, D.C., Lehmann, M., Yokoyama, J.S., Karydas, A., Lee, J.J., Coppola, G., Grinberg, L.T., Geschwind, D., Seeley, W.W., Miller, B.L., Rosen, H., and Rabinovici, G. 2013. Progranulin mutations as risk factors for Alzheimer disease. JAMA Neurol. 70: 774-778. [Medline] [CrossRef]

28. Pickford, F., Marcus, J., Camargo, L.M., Xiao, Q., Graham, D., Mo, J.R., Burkhardt, M., Kulkarni, V., Crispino, J., Hering, H., and Hutton, M. 2011. Progranulin is a chemoattractant for microglia and stimulates their endocytic activity. Am. J. Pathol. 178: 284-295. [Medline] [CrossRef]

29. Rosen, E.Y., Wexler, E.M., Versano, R., Coppola, G., Gao, F., Winden, K.D., Oldham, M.C., Martens, L.H., Zhou, P., Farese, R.V. Jr., and Geschwind, D.H. 2011. Functional genomic analyses identify pathways dysregulated by progranulin deficiency, implicating Wnt signaling. Neuron 71 : 1030-1042. [Medline] [CrossRef]

30. Sleegers, K., Brouwers, N., Van Damme, P., Engelborghs, S., Gijselinck, I., van der Zee, J., Peeters, K., Mattheijssens, M., Cruts, M., Vandenberghe, R., De Deyn, P.P., Robberecht, W., and Van Broeckhoven, C. 2009. Serum biomarker for progranulin-associated frontotemporal lobar degeneration. Ann. Neurol. 65: 603-609. [Medline] [CrossRef]

31. Spina, S., Murrell, J.R., Huey, E.D., Wassermann, E.M., Pietrini, P., Grafman, J., and Ghetti, B. 2007. Corticobasal syndrome associated with the A9D Progranulin mutation. $J$. Neuropathol. Exp. Neurol. 66: 892-900. [Medline] [CrossRef]

32. Takahashi, H., Klein, Z.A., Bhagat, S.M., Kaufman, A.C., Kostylev, M.A., Ikezu, T., Strittmatter, S.M., Alzheimer's Disease Neuroimaging Initiative. 2017. Opposing effects of progranulin deficiency on amyloid and tau pathologies via microglial TYROBP network. Acta Neuropathol. 133: 785807. [Medline] [CrossRef]

33. Tanaka, Y., Chambers, J.K., Matsuwaki, T., Yamanouchi, K., and Nishihara, M. 2014. Possible involvement of lysosomal dysfunction in pathological changes of the brain in aged progranulin-deficient mice. Acta Neuropathol. Commun. 2: 78. [Medline] [CrossRef]

34. Tanaka, Y., Matsuwaki, T., Yamanouchi, K., and Nishihara, M. 2013. Increased lysosomal biogenesis in activated microglia and exacerbated neuronal damage after traumatic brain injury in progranulin-deficient mice. Neuroscience 250: 8-19. [Medline] [CrossRef]

35. Tanaka, Y., Suzuki, G., Matsuwaki, T., Hosokawa, M., Serrano, G., Beach, T.G., Yamanouchi, K., Hasegawa, M., and Nishihara, M. 2017. Progranulin regulates lysosomal function and biogenesis through acidification of lysosomes. Hum. Mol. Genet. 26: 969-988. [Medline]

36. Van Damme, P., Van Hoecke, A., Lambrechts, D., Vanacker, P., Bogaert, E., van Swieten, J., Carmeliet, P., Van Den Bosch, L., and Robberecht, W. 2008. Progranulin functions as a neurotrophic factor to regulate neurite outgrowth and enhance neuronal survival. J. Cell Biol. 181: 37-41. [Medline] [CrossRef]

37. Yin, F., Banerjee, R., Thomas, B., Zhou, P., Qian, L., Jia, T., Ma, X., Ma, Y., Iadecola, C., Beal, M.F., Nathan, C., and 
Ding, A. 2010. Exaggerated inflammation, impaired host defense, and neuropathology in progranulin-deficient mice. $J$. Exp. Med. 207: 117-128. [Medline] [CrossRef]

38. Zhu, J., Nathan, C., Jin, W., Sim, D., Ashcroft, G.S., Wahl,
S.M., Lacomis, L., Erdjument-Bromage, H., Tempst, P., Wright, C.D., and Ding, A. 2002. Conversion of proepithelin to epithelins: roles of SLPI and elastase in host defense and wound repair. Cell 111: 867-878. [Medline] [CrossRef] 